\title{
Mathematical and experimental study of hydrogen sulfide concentrations in the Kahrizak landfill, Tehran, Iran
}

\author{
Gholamreza Asadollahfardi $^{{ }^{\dagger}}$, Safora Mazinani ${ }^{1}$, Mohsen Asadi ${ }^{2}$, Mohsen Mirmohammadi ${ }^{3}$ \\ ${ }^{1}$ Civil Engineering Department, Technical and Engineering Faculty, Kharazmi University, Tehran, 15719-14911, Iran \\ ${ }^{2}$ College of Engineering, University of Saskatchewan, Saskatoon, SK, S7N 5A9, Canada \\ ${ }^{3}$ Faculty of Environment, University of Tehran, Tehran, 14155-6135, Iran
}

\begin{abstract}
The emission of hydrogen sulfide $\left(\mathrm{H}_{2} \mathrm{~S}\right)$ from the Kahrizak landfill was studied. Firstly, the field measurements were conducted in the summer and winter seasons; and the samples were analyzed using Jacob method. We predicted the $\mathrm{H}_{2} \mathrm{~S}$ concentrations in the downwind using AERMOD and ISCST3. According to the AERMOD, the maximum concentration of $\mathrm{H}_{2} \mathrm{~S}$ in the summer and winter were $117 \mu \mathrm{g} / \mathrm{m}^{3}$ and $205 \mu \mathrm{g} / \mathrm{m}^{3}$, respectively. The downwind concentrations reached zero at the distance of $35 \mathrm{~km}$ from the leachate treatment plant. The Geometric mean bias, Geometric variance, Fractional bias, Fraction of predictions within a factor of two of the observations and Normalized mean square error for the AERMOD were $0.58,1.35,-0.12,1.91$ and 0.042 , respectively in the summer and 1.39, 1.35, $-0.05,1.46$ and 0.027 in the winter; and for the ISCST3, were $0.85,1.03,0.02,1.45$ and 0.04 in the summer and 1.18, 1.03, 0.15, 1.16 and 0.04 in the winter. The results of the AERMOD were compared with the ISCST3 and indicated that the AERMOD performance was more suitable than the ISCST3.
\end{abstract}

Keywords: AERMOD, Hydrogen sulfide emission modeling, ISCST3, Landfill

\section{Introduction}

Municipal solid waste (MSW) landfills are potential sources of the offensive odor emission and annoyance in neighboring urban areas. The odor pollution has become a growing concern during the last decades for urban communities. The annoying odors released to the atmosphere from landfills may cause decreased quality of life, and possibly more negative consequences for human health and welfare [1].

Many people in the world have complained against emission of odor [2-4]. The odor has a considerable impact on the health of people such as triggering possible harmful reflexes and modifying olfactory function [2].

Hydrogen sulfide $\left(\mathrm{H}_{2} \mathrm{~S}\right)$ is a colorless, flammable, very toxic and dangerous gas with rotten egg smell. The main way of exposure is inhalation and can swiftly be absorbed by the lungs. The Human can smell the odor of $\mathrm{H}_{2} \mathrm{~S}$ at low concentration in the air. $\mathrm{H}_{2} \mathrm{~S}$ as an irritant and a chemical asphyxiate influences on the control nervous system and oxygen utilization and at the low concentration and irritates the nose, eyes, throat and respiratory system [5, 6].
Odor (particularly $\mathrm{H}_{2} \mathrm{~S}$ ) control is a major concern in the operation of existing landfills as well as in the design of future landfills for complying with the odor standard [7]. The odor emission rate depends on several factors, such as the thickness of the cover, the age of the waste, type of cover, the landfill moisture. The odor emission is affected by the wind speed, wind direction, atmospheric conditions, temperature and topographic conditions of the region [8].

To assess odor pollution impacts in the downwind, mathematical modeling is a cost effective and less time consuming and can be assumed as a valuable substitute for the field measurements. Pollution plume modeling can give us pollutant concentrations in the air over a period of time in any geographic location. This is a good way to assess the effects of pollution sources on the quality of air in the surrounding area. In most of models that relate to the emission of gases, a Gaussian Plume method is used.

Schauberger et al. [9] predicted the emission rate of $\mathrm{H}_{2} \mathrm{~S}$ of a wastewater treatment plant based on its environmental concentrations and meteorological parameters. Hanna et al. [10] examined
This is an Open Access article distributed under the terms of the Creative Commons Attribution Non-Commercial License (http://creativecommons.org/licenses/by-nc/3.0/) which permits unrestricted non-commercial use, distribution, and reproduction in any medium, provided the original work is properly cited.

Copyright (C) 2019 Korean Society of Environmental Engineers
Received July 31, 2018 Accepted November 23, 2018

${ }^{\dagger}$ Corresponding author

Email: asadollahfardi@yahoo.com

Tel: +98-912-1192-424

ORCID: 0000-0002-7867-8757 
the predicted air pollutant concentrations by AERMOD and ISC3 models for the 5 field data series, and the results indicated that the AERMOD predictions was closer to experimental data.

Plaza et al. [11] selected five types of cover for landfill, including sandy soil, sandy soil amended with lime, clayey soil, fine concrete to control $\mathrm{H}_{2} \mathrm{~S}$. The sandy soil amended with lime and the fine concrete were most effective for control $\mathrm{H}_{2} \mathrm{~S}$ emission. $\mathrm{Xu}$ et al. [12] checked the emission rate of $\mathrm{H}_{2} \mathrm{~S}$ from a landfill with the different landfill cover material. They indicated that the compost, yard trash and soil amended with quicklime and calcium carbonate covers attenuated $\mathrm{H}_{2} \mathrm{~S}$ emission rate.

Saral et al. [7] modeled $\mathrm{H}_{2} \mathrm{~S}$ and 22 VOCs using ISCST3 to forecast, hourly concentration of odor. Their results indicated that the short term average of three of VOCs namely ethyl mercaptan, methyl mercaptan and $\mathrm{H}_{2} \mathrm{~S}$ did exceed their odor threshold. Latos et al. [13] measured the $\mathrm{H}_{2} \mathrm{~S}$ concentration at the different locations during the summer by a portable device in a wastewater treatment plant in Greece and used AERMOD Gaussian model to estimate maximum odor concentration.

Jeong [14] used an AERMOD model to predict odor concentration (regardless of the type of odorous gas, measured based on odor unit) around an industrial complex. Samples were collected at the site in 11 stations and during $5 \mathrm{~d}$, and the meteorological data were measured on the site. Bolyard [8] measured the concentrations of $\mathrm{H}_{2} \mathrm{~S}$ gas at different locations in Florida landfill and estimated the emission rate by using the modeling method and then calculated the $\mathrm{H}_{2} \mathrm{~S}$ buffering distance by AERMOD model. Rood [15] reviewed the efficiency of the diffusion modeling software such as AERMOD. He measured the ratio of the simulated to the field and calculating the differences in percentages. The ratio varied between $5 \%$ to $85 \%$ of cases that indicate the suitability of the AERMOD model.

Asadollahfardi et al. [4] evaluated the efficiency of ISC3 model to simulate the ammonia emission from Kahrizak landfill. The predicted concentrations at a distance less than $300 \mathrm{~m}$ from the sources had a deep gap in comparison with the field measurement. However, at a distance more than $300 \mathrm{~m}$, ISC had a good performance.

On the one side, to the best knowledge of the authors, the emission of $\mathrm{H}_{2} \mathrm{~S}$ from landfills has not sufficiently been discussed in terms of experimental and mathematical studies.

The odor pollution has influenced human welfare and gave rise to some concerns among the people who settle in the nearby of the Kahrizak landfill and raising public criticisms against the local jurisdictions. In addition, the odorous pollution is a nauseating issue for the passengers who travel to the international airport via the surrounding highways [4]. The adverse health effects of exposure to $\mathrm{H}_{2} \mathrm{~S}$ have not been sufficiently addressed and the results of study of different researchers are inconsistent. The vital health effects from a low level and chronic exposure have not still been reported [16]. Nonetheless, the exposure to $\mathrm{H}_{2} \mathrm{~S}$ in concentrations of $10 \mathrm{ppm}$ to $500 \mathrm{ppm}$ may negatively influence the central nervous system, respiratory and blood issues, especially vulnerable populations such as children with asthma $[17,18]$.

The first aim of this study was to monitor $\mathrm{H}_{2} \mathrm{~S}$ concentrations in the downwind of the Kahrizak landfill during the winter and summer seasons. The measurements were compared with each other to demonstrate the environmental situation in the observed data. Afterwards, we employed the AERMOD and ISCST3 models to estimate the $\mathrm{H}_{2} \mathrm{~S}$ concentrations at the upwind and downwind. The results were assessed using the observed data to reveal the suitable model for estimating $\mathrm{H}_{2} \mathrm{~S}$ emission.

\section{Materials and Methods}

\subsection{The Study Area}

The study area was Kahrizak complex, which covered a surface area of $14 \mathrm{~km}^{2}$ and located in the south of Tehran, Iran [19]. The geographic coordinate of the study area is $35^{\circ} 27^{\prime} 52^{\prime \prime} \mathrm{N}$ and $51^{\circ} 19^{\prime} 19^{\prime \prime} \mathrm{E}$. The elevation of the complex varies from $1,020 \mathrm{~m}$ to $1,060 \mathrm{~m}$ [3]. The prevailing wind directions are westerly and northwesterly winds. The average annual temperature varies from $-5^{\circ} \mathrm{C}$ to $40^{\circ} \mathrm{C}$. The annual mean precipitation and evaporation are $240 \mathrm{~mm}$ and $250 \mathrm{~mm}$, respectively [20].

Averagely, about 7,500 tons per day of municipal solid waste is unloaded at the complex, which $50 \%$ transferred to the composting site, $5 \%$ managed to reuse, and $45 \%$ disposed in the landfill. Totally, a daily average of 3,600 tons of valueless dry waste enters into the complex, due to the high thermal value of these wastes, 200 tons per day is transferred to an incinerator for combustion, which produces 2 MW electricity [19]. The Kahrizak Complex consists of landfills A and B, landfill A was operated in 1973 and closed in 1998, and landfill B started operating in 1998 and will be closed by 2020. One leachate treatment plant with a capacity of 1,400 cubic meters per is active in the complex.

\subsection{Field Measurement of Atmospheric $\mathrm{H}_{2} \mathrm{~S}$}

Due to the prevailing wind direction and accessibility, we selected eleven locations to monitor hydrogen sulfide in the summer and winter, respectively. The access to the eastern region of emission sources was limited, which was assumed as a restriction ahead of the field measurement. Table 1 indicates the position of monitoring station related to the landfills $\mathrm{A}$ and $\mathrm{B}$. The measurements were not carried out in the rainy days. Rainfall causes substantial pollutant concentration decline by washing out particles and absorbing pollutants $[21,22]$. In addition, site accessing in the rainy weather and experimental expenses were other research limitations.

To measure $\mathrm{H}_{2} \mathrm{~S}$ concentration, the variation of the methylene blue after exposure to the ambient air was analyzed (Jacobs method) [20]. Using a sampling pump in a flowrate between 1 to 1.5 $\mathrm{L} / \mathrm{min}$, the air was bubbled through $45 \mathrm{~mL}$ absorption solution in a macro impinger. The sampling time varied between 30 to 45 min. The sampling pump was universal PCXR8, manufactured by SKC United Kingdom.

We added amine test reagent and ferric chloride solution to the collected samples. Afterwards, we agitated the mixture and waited for $30 \mathrm{~min}$ to assure the reaction was done. The $\mathrm{H}_{2} \mathrm{~S}$ concentration was obtained using a spectrophotometer (DR 2800) at $670 \mathrm{~nm}$ wavelength [23]. 
Table 1. Site and Weather Condition in the Autumn Season

\begin{tabular}{|c|c|c|c|c|c|c|c|c|c|c|c|}
\hline \multirow[t]{2}{*}{ Station } & \multirow{2}{*}{$\begin{array}{l}\text { Geographical } \\
\text { coordination }\end{array}$} & \multicolumn{2}{|c|}{ Time of sampling } & \multicolumn{2}{|c|}{ Temperature $\left({ }^{\circ} \mathrm{C}\right)$} & \multicolumn{2}{|c|}{$\begin{array}{l}\text { Average wind speed } \\
\qquad(\mathrm{m} / \mathrm{s})\end{array}$} & \multicolumn{2}{|c|}{ Wind direction } & \multirow{2}{*}{$\begin{array}{c}\text { DLA } \\
\text { (m) }\end{array}$} & \multirow{2}{*}{$\begin{array}{c}\text { DLB } \\
(\mathrm{m})\end{array}$} \\
\hline & & summer & winter & summer & winter & summer & winter & summer & winter & & \\
\hline 1 & $\begin{array}{l}35^{\circ} 27^{\prime} 30^{\prime \prime} \mathrm{N} \\
51^{\circ} 20^{\prime} 29^{\prime \prime} \mathrm{E}\end{array}$ & $08 / 24 / 16$ & $02 / 22 / 17$ & 28 & 9 & 2.22 & 5.5 & S-SW & W & 130 & 480 \\
\hline 2 & $\begin{array}{c}35^{\circ} 28^{\prime} 0.0^{\prime \prime} \mathrm{N} \\
51^{\circ} 19^{\prime} 59^{\prime \prime} \mathrm{E}\end{array}$ & $08 / 24 / 16$ & $02 / 22 / 17$ & 28 & 9 & 2.22 & 5.5 & S-SW & W & 360 & 150 \\
\hline 3 & $\begin{array}{c}35^{\circ} 28^{\prime} 0.0^{\prime \prime} \mathrm{N} \\
51^{\circ} 19^{\prime} 20^{\prime \prime} \mathrm{E}\end{array}$ & $08 / 24 / 16$ & $02 / 22 / 17$ & 28 & 9 & 2.22 & 5.5 & S-SW & $\mathrm{W}$ & 750 & 862 \\
\hline 4 & $\begin{array}{l}35^{\circ} 27^{\prime} 55^{\prime \prime} \mathrm{N} \\
51^{\circ} 19^{\prime} 30^{\prime \prime} \mathrm{E}\end{array}$ & $08 / 24 / 16$ & $02 / 22 / 17$ & 28 & 9 & 2.22 & 5.5 & S-SW & $\mathrm{W}$ & 185 & 400 \\
\hline 5 & $\begin{array}{l}35^{\circ} 28^{\prime} 18^{\prime \prime} \mathrm{N} \\
51^{\circ} 19^{\prime} 47^{\prime \prime} \mathrm{E}\end{array}$ & $08 / 24 / 16$ & $02 / 22 / 17$ & 28 & 9 & 2.22 & 5.5 & S-SW & $\mathrm{W}$ & 960 & 380 \\
\hline 6 & $\begin{array}{l}35^{\circ} 29^{\prime} 27^{\prime \prime} \mathrm{N} \\
51^{\circ} 15^{\prime} 06^{\prime \prime} \mathrm{E}\end{array}$ & - & $02 / 22 / 17$ & - & 9 & - & 5.5 & - & S-SW & 7,530 & 7,811 \\
\hline 7 & $\begin{array}{l}35^{\circ} 29^{\prime} 11^{\prime \prime} \mathrm{N} \\
51^{\circ} 14^{\prime} 50^{\prime \prime} \mathrm{E}\end{array}$ & - & $02 / 22 / 17$ & - & 9 & - & 5.5 & - & S-SW & 7,782 & 8,047 \\
\hline 8 & $\begin{array}{l}35^{\circ} 28^{\prime} 52^{\prime \prime} \mathrm{N} \\
51^{\circ} 14^{\prime} 37^{\prime \prime} \mathrm{E}\end{array}$ & - & $02 / 22 / 17$ & - & 9 & - & 5.5 & - & S-SW & 8,137 & 8,202 \\
\hline 9 & $\begin{array}{l}35^{\circ} 26^{\prime} 31^{\prime \prime} \mathrm{N} \\
51^{\circ} 12^{\prime} 18^{\prime \prime} \mathrm{E}\end{array}$ & - & $02 / 22 / 17$ & - & 9 & - & 5.5 & - & S-SW & 11,566 & 12,252 \\
\hline 10 & $\begin{array}{l}35^{\circ} 26^{\prime} 19^{\prime \prime} \mathrm{N} \\
51^{\circ} 12^{\prime} 14^{\prime \prime} \mathrm{E}\end{array}$ & - & $02 / 22 / 17$ & - & 9 & - & 5.5 & - & S-SW & 11,608 & 12,188 \\
\hline 11 & $\begin{array}{l}35^{\circ} 29^{\prime} 48^{\prime \prime} \mathrm{N} \\
51^{\circ} 20^{\prime} 47^{\prime \prime} \mathrm{E}\end{array}$ & $08 / 24 / 16$ & - & 28 & - & 2.22 & - & S-SW & - & 3,981 & 3,146 \\
\hline
\end{tabular}

DLA $=$ Distance relative to the landfill $\mathrm{A}$

$\mathrm{DLB}=$ Distance relative to the landfill $\mathrm{B}$

\subsection{Dispersion Models}

The basic Gaussian dispersion equation considers a constantly releasing point source emanating via a coordinate system with its origin at the base of the source. Eq. (1) depicts the Gaussian diffusion equation for predicting ground level concentrations directly downwind from a point source [24]

$$
\begin{gathered}
C=\frac{Q}{2 \pi \sigma_{y} \sigma_{z} \bar{u}} \exp \left(-\frac{y^{2}}{2 \sigma_{y}^{2}}\right) \\
\left\{\exp \left(-\frac{\left(z+H_{e}\right)^{2}}{2 \sigma_{z}^{2}}\right)+\exp \left(-\frac{\left(z-H_{e}\right)^{2}}{2 \sigma_{z}^{2}}\right)\right\}
\end{gathered}
$$

Where $C$ is the concentration $\left(\mu \mathrm{g} / \mathrm{m}^{3}\right)$ at $(\mathrm{x}, \mathrm{y}, \mathrm{z})$ and $Q$ is the emission rate $(\mu \mathrm{g} / \mathrm{s} ., \sigma z$ and $\sigma y$ are the vertical and horizontal spread parameters, which are functions of the distance (X) from emission, and atmospheric stability class and $u$ is the average wind speed in $(\mathrm{m} / \mathrm{s}), z$ is the vertical distance above the ground in (m), $y$ is the horizontal distance from the centerline of the plume (m), $H$ is the effective height of the stack (m).

The ISCST-3 model deploys a steady-state Gaussian flow equation for modelling the dispersion of emissions from various sources [25] (Eq. (2) to (4)).

$$
\begin{gathered}
C=\frac{Q_{P}}{\pi \sigma_{y} \sigma_{z} u} \exp \left(-\frac{y^{2}}{2 \sigma_{y}^{2}}\right) \exp \left(-\frac{H^{2}}{2 \sigma_{z}^{2}}\right) \\
C=\frac{2 Q_{L}}{\sqrt{2 \pi} \sigma_{z} u} \exp \left(-\frac{H^{2}}{2 \sigma_{z}^{2}}\right) \\
C=\frac{Q_{A}}{2 \pi u} \int_{X} \frac{V}{\sigma_{y} \sigma_{z}}\left(\int_{Y} \exp \left[-\frac{y^{2}}{2 \sigma_{y}^{2}}\right] d y\right) d x
\end{gathered}
$$

Where $C$ is the downwind pollutant concentration $\left(\mathrm{g} / \mathrm{m}^{3}\right), Q_{\mathrm{p}}$ is the point source pollutant emission rate $(\mathrm{g} / \mathrm{s}), Q_{\mathrm{L}}$ is line source pollutant emission rate $(\mathrm{g} / \mathrm{ms}) . Q_{\mathrm{A}}$ is the area source odor emission rate $\left(\mathrm{g} / \mathrm{m}^{2} \mathrm{~s}\right), \sigma_{y}$ and $\sigma_{z}$ are the Pasquill-Gifford plume spread parameters based on stability class, $u$ is the average wind speed at pollutant release height $(\mathrm{m} / \mathrm{s}) . H$ is the effective height above ground of emission source (m). $V$ is the vertical term used to describe vertical distribution of the plume and $x$ is the upwind direction $(\mathrm{m})$, and $y$ the cross wind direction $(\mathrm{m})$.

AERMOD as a steady-state Gaussian dispersion model that is able to compute contaminants spreading from point, area and volume sources in rural and urban areas. The model assumes that a ratio of the plume (moved from a buoyant source) goes 
up and stays near the top of the boundary layer [26]. The model simulates flat and complex terrains in stable and convective boundary layers (SBL and CBL). In the stable condition, a Gaussian probability distribution function is employed to anticipate the concentration of a contaminant in vertical and horizontal directions. In convective situation, the horizontal and vertical dispersions are defined by Gaussian and Bi-Gaussian probability distribution functions, respectively [27, 28]. The model holds two preprocessors, encompassing AERMET and AERMAP. AERMET calculates boundary layer parameters, entailing friction velocity $(u *)$, Monin-Obukhov length $(L)$, convective velocity scale $\left(W_{*}\right)$, temperature scale $(\theta *)$, mixing height $\left(z_{i}\right)$ and surface heat flux $(H)$. Therefore, the vertical profiles of wind speed $(u)$, lateral and vertical turbulence fluctuations $\left(\sigma_{\mathrm{v}}, \sigma_{\mathrm{w}}\right)$, potential temperature gradients $(d \theta / d z)$ and potential temperatures $(\theta)$ can be computed [26, 29]. AERMAP uses gridded terrain data to analyze a representative terrain influence height $\left(h_{c}\right)$ in each receptor location. $h_{c}$ can specify the dividing streamline height. In addition, AERMAP presents the receptor's location $\left(x_{r}, y_{r}\right)$, its height above mean sea level $\left(z_{r}\right)$ and $h_{c}$. AERMOD applies the processed data from AERMET and AERMAP to obtain concentrations of the pollutant (Eq. (5)).

$$
\begin{aligned}
& C_{T}\left\{x_{r}, y_{r}, z_{r}\right\}= \\
& \quad f . C_{C, S}\left\{x_{r}, y_{r}, z_{r}\right\}+(1-f) C_{C, S}\left\{x_{r}, y_{r}, z_{p}\right\}
\end{aligned}
$$

Where $C_{T}\left\{x_{r}, y_{r}, z_{r}\right\}$ is the total concentration; $C_{C, S}\left\{x_{r}, y_{r}, z_{r}\right\}$ is the contribution from the horizontal plume state in convective $(C)$ and stable $(S)$ condition. $C_{C S}\left\{x_{r}, y_{r}, z_{p}\right\}$ is the contribution from the terrain - following state. $f$ is the plume state weighting function; $\left\{x_{r}, y_{r}, z_{r}\right\}$ is the coordinate representation of a receptor, which $z_{r}$ measured relative to stack base elevation. $z_{p}=z_{r}-z_{t}$ is the height of a receptor above local ground and $z_{t}$ is the terrain height at a receptor (in flat terrain $z_{t}=0$ ). A complete and comprehensive explanation of the AERMOD can be found in [26].

AERMOD View, which developed by Lakes Environmental ${ }^{\mathrm{TM}}$, includes EPA's AERMOD and ISCST3 models. The meteorological data is the backbone of the meteorological processor, which entails wind speed, wind direction, precipitation, station pressure, dew point, temperature, relative humidity and sky cover. The meteorological data was obtained from Imam Khomeini International Airport, located in the distance of $16.5 \mathrm{~km}$ from the complex and the altitude of $990 \mathrm{~m}$ from the sea level.

Input data to the models includes meteorological data, albedo coefficient, Bowen coefficient and roughness length, meteorological data was obtained from the nearest meteorological station, Imam Khomeini international airport. The study area was considered as a rural area and the type of terrain was considered flat because there are not significant up and down in the region. The albedo coefficient, Bowen coefficient and roughness length, assuming that the study area is desert terrain, was considered to be $0.3275,4.75$ and 0.2625 , using the coefficients determined by the Environmental Protection Agency for the desert terrain [28]. The emission rate, topography of the area, the characteristics of the existing buildings in the region, and the characteristics of the sources of publication, such as area and geographic location, were also given to the models.

\subsection{Model Efficiency}

The convergence of AERMOD predictions with the field measurement was evaluated using the the coefficient of determination $\left(\mathrm{R}^{2}\right)$, Index of agreement (d) and Nash-Sutcliffe coefficient (E), which are shown in Eq. (6) to (8) [30-32]:

$$
\begin{gathered}
R^{2}=\frac{\left(\sum\left(O_{i}-\bar{O}\right)\left(P_{i}-\bar{P}\right)\right)^{2}}{\sum\left(O_{i}-\bar{O}\right)^{2} \sum\left(P_{i}-\bar{P}\right)^{2}} \\
d=1-\frac{\sum_{i=1}^{N}\left(O_{i}-P_{i}\right)^{2}}{\sum_{i=1}^{N}\left(\left|P_{i}-\bar{O}\right|+\left|O_{i}-\bar{O}\right|\right)^{2}} \\
E=1-\frac{\sum_{i=1}^{N}\left(P_{i}-O_{i}\right)^{2}}{\sum_{i=1}^{N}\left(O_{i}-\bar{O}\right)^{2}}
\end{gathered}
$$

Where $O_{i}$ is the observed concentration; $P_{i}$ is the predicted concentration; $N$ is the number of stations and $\bar{O}$ is the mean field concentrations. While the results of $\mathrm{R}^{2}$, $\mathrm{d}$ and $\mathrm{E}$ approach to one, the model efficiency are very well.

In addition, Geometric mean bias (MG), Geometric variance (VG), Fraction of predictions within a factor of two of the observations (FAC2), Fractional bias (FB) and Normalized mean square error (NMSE) were used to evaluate the model efficiencies, which recommended by EPA [33]. Eq. (9) to (13) describe them:

$$
\begin{gathered}
M G=\exp \left(\overline{\ln C_{o}}-\overline{\ln C_{p}}\right)=\exp \overline{\left.\ln \left(\frac{C_{o}}{C_{p}}\right)\right)} \\
V G=\exp \left[\overline{\left(\ln C_{o}-\ln C_{p}\right)^{2}}\right] \\
F A C 2=C_{p} / C_{o} \\
F B=\frac{\sum\left(C_{o}-C_{p}\right)}{0.5 \sum\left(C_{o}+C_{p}\right)} \\
N M S E=\overline{\left(C_{o}-C_{p}\right)^{2}} / \overline{\left.C_{o} C_{p}\right)}
\end{gathered}
$$

Where $C_{o}$ and $C_{P}$ represent the measured and estimated concentrations, respectively. The value of 1 for MG, VG and FAC2 shows the perfect performance of the model. FB and MG are measures of mean relative bias and indicate only systematic errors, whereas NMSE and VG are measures of mean relative scatter and reflect both systematic and unsystematic (random) errors.

FAC2 quantitatively assesses the model scatter. If the fraction of model prediction within a factor of two observations is $50 \%$, then it is a good performing model. The value of 0 for the FB and NMSE indicates the ideal efficiency of the model. The FB and NMSE are linear indices and sensitive to the high 
concentrations. The MG and VG, as logarithmic indices, are more flexible to the variation of data. MG is used for the determination of model overestimation (MG > 1) and underestimation (MG < 1). Nonetheless, $\mathrm{MG}=1$ does not mean that predictions coincide with measurements.

\section{Results and Discussion}

\subsection{Field Concentrations}

As shown in Table 2, the monitoring indicated that the $\mathrm{H}_{2} \mathrm{~S}$ concentrations in the winter were generally higher than the summer, which demonstrated that the temperature might not be a crucial factor affecting the gas emission. Williams [34] reported that the weather changes might not be effective in the bacteria activities and consequently gas emission rate at the depths of landfill.

Table 2. The Average Concentration of Two Samples Taken Simultaneously at Each Station

\begin{tabular}{cccc}
\hline \multirow{2}{*}{ Station } & Geographical coordination & \multicolumn{2}{c}{ Concentration (ppb) } \\
\cline { 3 - 4 } summer & winter \\
\hline 1 & $35^{\circ} 27^{\prime} 30^{\prime \prime} \mathrm{N} 51^{\circ} 20^{\prime} 29^{\prime \prime} \mathrm{E}$ & 94.7 & 145 \\
2 & $35^{\circ} 28^{\prime} 0.0^{\prime \prime} \mathrm{N} 51^{\circ} 19^{\prime} 59^{\prime \prime} \mathrm{E}$ & 7.948 & 11 \\
3 & $35^{\circ} 28^{\prime} 0.0^{\prime \prime} \mathrm{N} 51^{\circ} 19^{\prime} 20^{\prime \prime} \mathrm{E}$ & 10.54 & 2 \\
4 & $35^{\circ} 27^{\prime} 55^{\prime \prime} \mathrm{N} 51^{\circ} 19^{\prime} 30^{\prime \prime} \mathrm{E}$ & 3.45 & 8 \\
5 & $35^{\circ} 28^{\prime} 18^{\prime \prime} \mathrm{N} 51^{\circ} 19^{\prime} 47^{\prime \prime} \mathrm{E}$ & 6.29 & 14 \\
6 & $35^{\circ} 29^{\prime} 27^{\prime \prime} \mathrm{N} 51^{\circ} 15^{\prime} 06^{\prime \prime} \mathrm{E}$ & - & 16 \\
7 & $35^{\circ} 29^{\prime} 11^{\prime \prime} \mathrm{N} 51^{\circ} 14^{\prime} 50^{\prime \prime} \mathrm{E}$ & - & 4 \\
8 & $35^{\circ} 28^{\prime} 52^{\prime \prime} \mathrm{N} 51^{\circ} 14^{\prime} 37^{\prime \prime} \mathrm{E}$ & - & 3.5 \\
9 & $35^{\circ} 26^{\prime} 31^{\prime \prime} \mathrm{N} 51^{\circ} 12^{\prime} 18^{\prime \prime} \mathrm{E}$ & - & 4 \\
10 & $35^{\circ} 26^{\prime} 19^{\prime \prime} \mathrm{N} 51^{\circ} 12^{\prime} 14^{\prime \prime} \mathrm{E}$ & - & 3 \\
11 & $35^{\circ} 29^{\prime} 48^{\prime \prime} \mathrm{N} 51^{\circ} 20^{\prime} 47^{\prime \prime} \mathrm{E}$ & 2.66 & - \\
\hline
\end{tabular}

According to the OSHA standard set by the US Labor Organization, the permitted concentration of $\mathrm{H}_{2} \mathrm{~S}$ is $20 \mathrm{ppm}$ and the maximum concentration for $10 \mathrm{~min}$. exposure is $50 \mathrm{ppm}$ [35]. According to the Massachusetts Environmental Protection
Organization, an hourly and $8 \mathrm{~h}$ limits of $\mathrm{H}_{2} \mathrm{~S}$ concentration are 30 and $15 \mathrm{ppb}$, respectively [36]. The station 1 was located near to the Landfill and refinery, where the average measured $\mathrm{H}_{2} \mathrm{~S}$ concentration was $119.58 \mathrm{ppb}$. This concentration did not meet the Massachusetts standard. While the detected $\mathrm{H}_{2} \mathrm{~S}$ in the other stations met the Massachusetts standard.

\section{2. $\mathrm{H}_{2} \mathrm{~S}$ Emission Rate}

The landfills and leachate treatment plants were assumed as the main sources of gas and $\mathrm{H}_{2} \mathrm{~S}$ emissions. The inflowrate, influent and effluent chemical oxygen demand (COD) in the leachate treatment were 1,400 m³/d, $55.5 \mathrm{~g} / \mathrm{L}$ and $0.8 \mathrm{~g} / \mathrm{L}$, respectively. Therefore, the removal rate of COD was 98.5\%. According to Youssefi [37], the emitted biogas could be $0.52 \mathrm{~L}$ per $1 \mathrm{~g}$ removed of COD. Therefore, the daily production of biogas from the leachate treatment plant could be $728 \mathrm{~m}^{3} / \mathrm{d}$, which $\mathrm{H}_{2} \mathrm{~S}$ contribution might vary between $0.728 \mathrm{~m}^{3} / \mathrm{d}$ to $7.28 \mathrm{~m}^{3} / \mathrm{d}$. Due to the density of $\mathrm{H}_{2} \mathrm{~S}$ (which is $1.36 \mathrm{~g} / \mathrm{L}$ ), the $\mathrm{H}_{2} \mathrm{~S}$ emission rates varied between 0.11 to $0.011 \mathrm{~g} / \mathrm{s}$. In 2016, the total gas emission from the landfill could be estimated around $14^{*} 10^{6} \mathrm{~m}^{3}$ and the contribution of $\mathrm{H}_{2} \mathrm{~S}$ varied between 0 to $1 \%$. Therefore, $\mathrm{H}_{2} \mathrm{~S}$ emission rate from the landfill might be assumed between 0 to $6 \mathrm{~g} / \mathrm{s}$. The emission rate of $\mathrm{H}_{2} \mathrm{~S}$ using Lang-gem software was obtained $1.1 \mathrm{~g} / \mathrm{s}$ [37].

The models were run in four scenarios with different $\mathrm{H}_{2} \mathrm{~S}$ emission rates, as shown below:

- Scenario 1: Emission from the landfill $(\mathrm{g} / \mathrm{s})=1.1$; Emission from the leachate treatment plant $(\mathrm{g} / \mathrm{s})=0.095$

- Scenario 2: Emission from the landfill $(\mathrm{g} / \mathrm{s})=1$; Emission from the leachate treatment plant $(\mathrm{g} / \mathrm{s})=0.09$

- Scenario 3: Emission from the landfill $(\mathrm{g} / \mathrm{s})=0.7$; Emission from the leachate treatment plant $(\mathrm{g} / \mathrm{s})=0.07$

- Scenario 4: Emission from the landfill $(\mathrm{g} / \mathrm{s})=0.65$; Emission from the leachate treatment plant $(\mathrm{g} / \mathrm{s})=0.07$

The AERMOD and ISCST3 estimations at the monitoring stations as well as the observed concentrations are indicated in Table 3.

\subsubsection{AERMOD output}

The level of $\mathrm{H}_{2} \mathrm{~S}$ in the sources varied between 100-117 $\mu \mathrm{g} / \mathrm{m}^{3}$ in the summer and between $200-205 \mu \mathrm{g} / \mathrm{m}^{3}$ in the winter (Fig. 1). $R^{2}, d$ and $E$ values between predicted and observed data in the summer were $0.98,0.98$ and 0.94 , respectively. While, the

Table 3. The Results of AERMOD and ISCST3 Models under Defined Scenarios

\begin{tabular}{|c|c|c|c|c|c|c|c|c|}
\hline \multirow{2}{*}{$\begin{array}{l}\mathrm{H}_{2} \mathrm{~S} \text { concentration in } \\
\text { the summer (ppb) }\end{array}$} & \multicolumn{2}{|c|}{ Scenario 1} & \multicolumn{2}{|c|}{ Scenario 2} & \multicolumn{2}{|c|}{ Scenario 3} & \multicolumn{2}{|c|}{ Scenario 4} \\
\hline & $\begin{array}{l}\text { AERMOD } \\
\text { (ppb) }\end{array}$ & $\begin{array}{l}\text { ISCST3 } \\
\text { (ppb) }\end{array}$ & $\begin{array}{l}\text { AERMOD } \\
\text { (ppb) }\end{array}$ & $\begin{array}{l}\text { ISCST3 } \\
\text { (ppb) }\end{array}$ & $\begin{array}{l}\text { AERMOD } \\
\text { (ppb) }\end{array}$ & $\begin{array}{c}\text { ISCST3 } \\
\text { (ppb) }\end{array}$ & $\begin{array}{l}\text { AERMOD } \\
\text { (ppb) }\end{array}$ & $\begin{array}{c}\text { ISCST3 } \\
\text { (ppb) }\end{array}$ \\
\hline 94.7 & 113.3 & 155.48 & 107.4 & 105.21 & 83.5 & 81.83 & 83.5 & 81.83 \\
\hline 7.94 & 34 & 43 & 30.9 & 27.96 & 21.9 & 19.57 & 20 & 18.14 \\
\hline 10.54 & 17.1 & 7.36 & 15.6 & 4.78 & 10.9 & 3.34 & 10 & 3.7 \\
\hline 3.45 & 14.6 & 18.6 & 13.3 & 12.08 & 9.3 & 8.43 & 8.6 & 7.79 \\
\hline 6.29 & 20.5 & 16 & 18.7 & 10.42 & 13.1 & 7.29 & 12.1 & 6.71 \\
\hline 2.66 & 13.1 & 12.23 & 11.9 & 7.97 & 8.4 & 5.57 & 7.1 & 5.21 \\
\hline Error (\%) & 59.5 & 64 & 56.1 & 52.3 & 43.8 & 44.7 & 41.6 & 42.3 \\
\hline
\end{tabular}



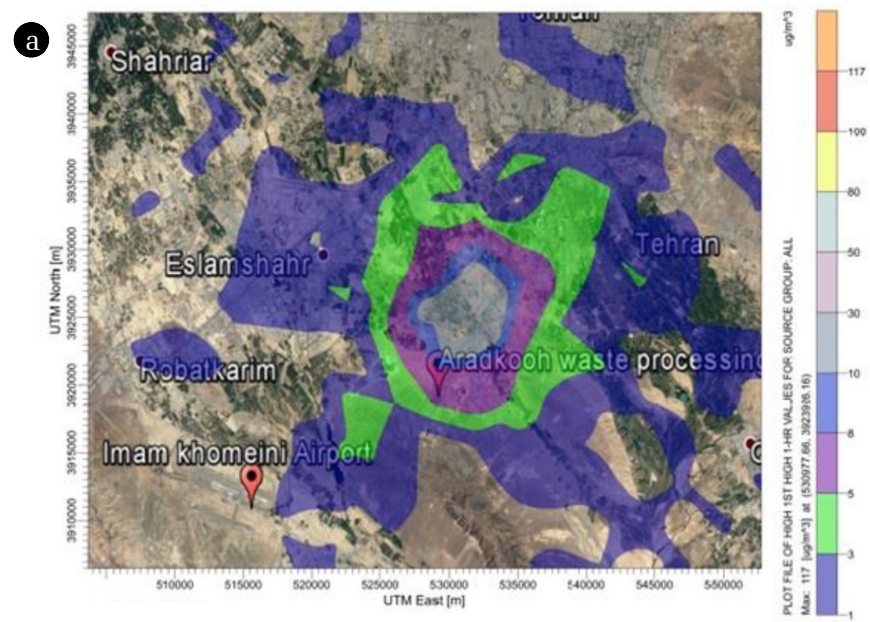

\begin{tabular}{|l|l|c|c|}
\hline Station & $\begin{array}{l}\text { Geographical } \\
\text { coordination }\end{array}$ & $\begin{array}{l}\text { Observation } \\
(\mathrm{ppb})\end{array}$ & $\begin{array}{l}\text { AERMOD } \\
(\mathrm{ppb})\end{array}$ \\
\hline 1 & $35^{\circ} 27^{\prime} 30^{\prime \prime} N 51^{\circ} 20^{\prime} 29^{\prime \prime} E$ & 94.7 & 83.5 \\
\hline 2 & $35^{\circ} 28^{\prime} 0^{\prime \prime} N 51^{\circ} 19^{\prime} 59^{\prime \prime} E$ & 7.95 & 20.0 \\
\hline 3 & $35^{\circ} 28^{\prime} 0^{\prime \prime} N 51^{\circ} 19^{\prime} 20^{\prime \prime} E$ & 10.5 & 10.0 \\
\hline 4 & $35^{\circ} 27^{\prime} 55^{\prime \prime} N 51^{\circ} 19^{\prime} 30^{\prime \prime} E$ & 3.45 & 8.60 \\
\hline 5 & $35^{\circ} 28^{\prime} 18^{\prime \prime} N 51^{\circ} 19^{\prime} 47^{\prime \prime} E$ & 6.29 & 12.1 \\
\hline 11 & $35^{\circ} 29^{\prime} 48^{\prime \prime} N 51^{\circ} 20^{\prime} 47^{\prime \prime} E$ & 2.66 & 7.10 \\
\hline
\end{tabular}
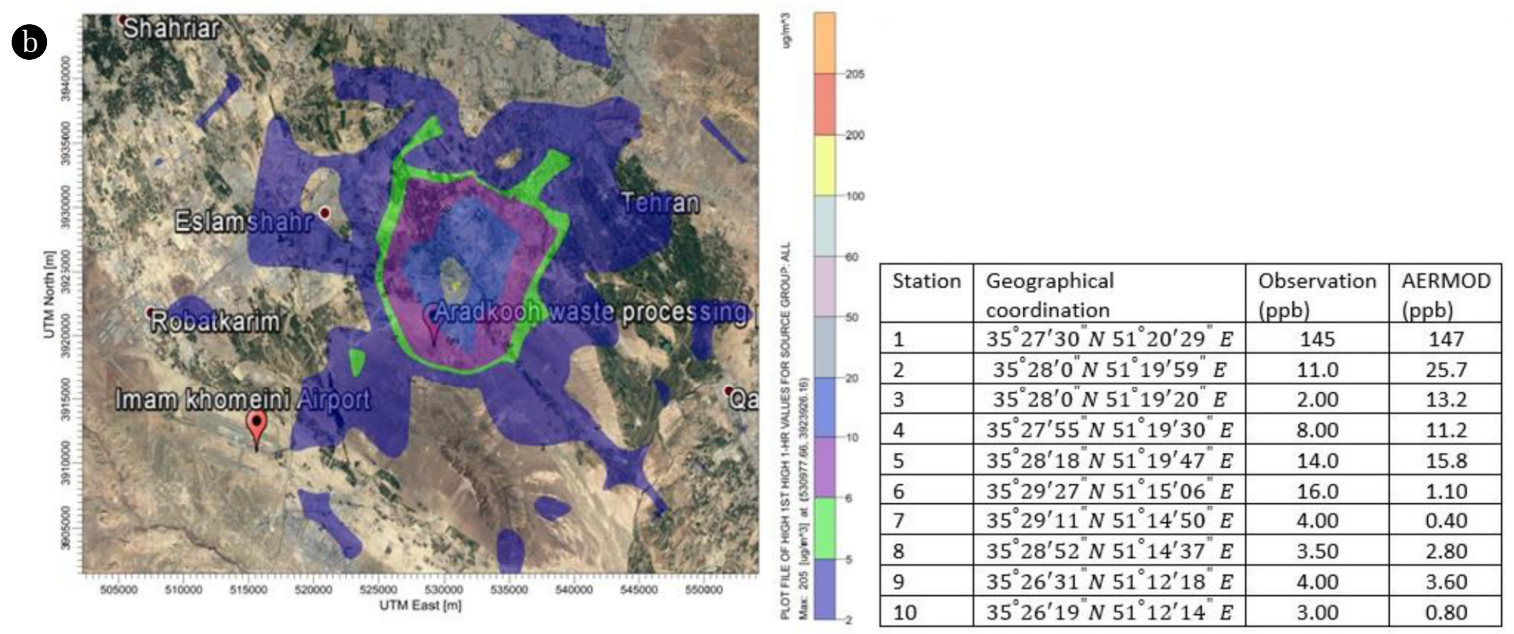

Fig. 1. Concentration contours output from the AERMOD model for the Kahrizak complex in the summer and winter. (a) Summer, (b) Winter

mentioned values in the winter were $0.96,0.99$ and 0.96 , respectively. Therefore, the predictions of the model were acceptable and robust.

\subsubsection{ISC output}

The maximum level of $\mathrm{H}_{2} \mathrm{~S}$ in the summer and winter were 123 $\mu \mathrm{g} / \mathrm{m}^{3}$ and $171 \mu \mathrm{g} / \mathrm{m}^{3}$, respectively (Fig. 2). $\mathrm{R}^{2}$, d and E values between predicted and observed data in the summer were 0.96 , 0.98 and 0.94 , respectively. While, the mentioned values in the winter were $0.98,0.98$ and 0.95 , respectively. Therefore, the predictions of the model were acceptable and robust.

The MG values for ISCST3 and AERMOD in the summer were less than 1, which shows the underestimation of model predictions. The values in the winter were larger than 1 , which means the overestimation of the predictions. Nonetheless, the ISCST3 predictions had more agreements with observed data. In the other words, the MG values were closer to 1 in comparison with AERMOD predictions. The VG for ISCST3 predictions in the summer and winter were closer to 1 in comparison with AERMOD anticipations, which shows the lesser variance from the mean value. The predictions of ISCST3 had lower FAC2, which indicates the model scatter was smaller. According to FB values, the AERMOD and ISCST3 predictions were overestimated and underestimated, respectively. In the summer, the prediction of ISCST3 was closer to the observed data. Nevertheless, the winter prediction of AERMOD was more accurate. The values of NMSE demonstrates a relatively well performing of the models in the space and time (Table 4).

The attained $\mathrm{R}^{2}$, $\mathrm{d}$ and $\mathrm{E}$ for AERMOD and ISCST3 models demonstrated the acceptable performance of both model in the prediction of $\mathrm{H}_{2} \mathrm{~S}$ emissions from the landfill and treatment plant. Nonetheless, the values of MG, VG, FAC2, FB and NMSE represented a relatively better performance of ISCST3.

Hanna et al. [10] examined the MG, VG and FAC2 values of the AERMOD model which were 1.70, 2.9 and 0.46, respectively, and these values in the ISC3 model were $0.70,7.7$ and 0.33 , respectively. They concluded that the AERMOD's performance was more accurate.

Jeong [14] used the AERMOD model to predict odor concentration (regardless of the type of odorous gas, measured based on odor unit). The values of FB, MG, NMSE, VG and FAC2 were equal to $-0.019,1.392,0.499,2.461$, and 1.019, respectively. He 

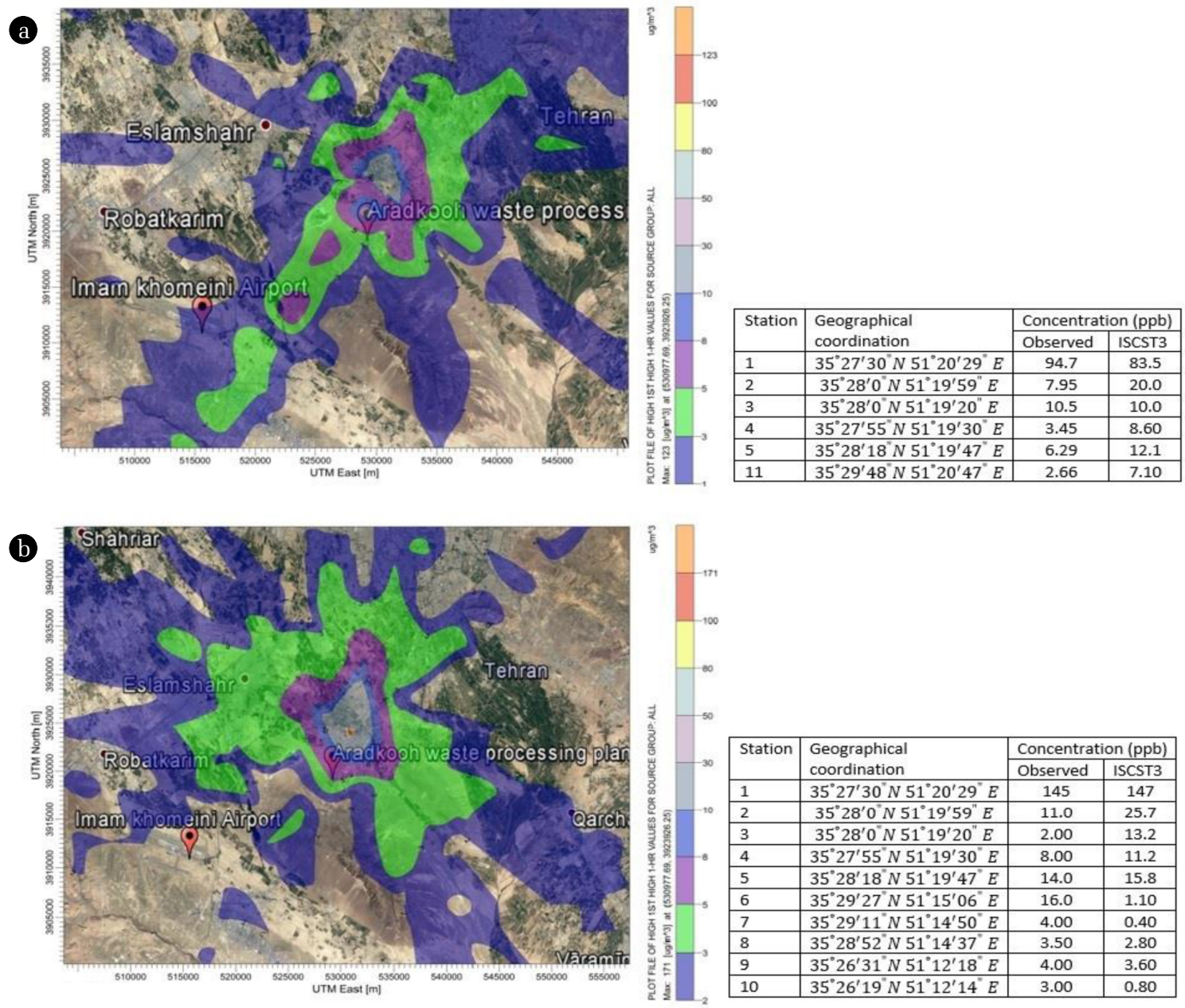

\begin{tabular}{|l|l|c|c|}
\hline Station & \multirow{2}{*}{$\begin{array}{l}\text { Geographical } \\
\text { coordination }\end{array}$} & \multicolumn{2}{|c|}{ Concentration (ppb) } \\
\cline { 3 - 4 } & $35^{\circ} 27^{\prime} 30^{\circ} N 51^{\circ} 20^{\prime} 29^{\circ} E$ & Observed & ISCST3 \\
\hline 1 & $35^{\circ} 28^{\prime} 0^{\circ} N 51^{\circ} 19^{\prime} 59^{\prime \prime} E$ & 11.0 & 147 \\
\hline 2 & $35^{\circ} 28^{\prime} 0^{\circ} N 51^{\circ} 19^{\prime} 20^{\prime \prime} E$ & 2.00 & 25.7 \\
\hline 3 & $35^{\circ} 27^{\prime} 55^{\circ} N 51^{\circ} 19^{\prime} 30^{\circ} E$ & 8.00 & 13.2 \\
\hline 4 & $35^{\circ} 28^{\prime} 18^{\circ} N 51^{\circ} 19^{\prime} 47^{\circ} E$ & 14.0 & 15.8 \\
\hline 5 & $35^{\circ} 29^{\prime} 27^{\circ} N 51^{\circ} 15^{\prime} 06^{\circ} E$ & 16.0 & 1.10 \\
\hline 6 & $35^{\circ} 29^{\prime} 11^{\circ} N 51^{\circ} 14^{\prime} 50^{\circ} E$ & 4.00 & 0.40 \\
\hline 7 & $35^{\circ} 28^{\prime} 52^{\circ} N 51^{\circ} 14^{\prime} 37^{\circ} E$ & 3.50 & 2.80 \\
\hline 8 & $35^{\circ} 26^{\prime} 31^{\circ} N 51^{\circ} 12^{\prime} 18^{\circ} E$ & 4.00 & 3.60 \\
\hline 9 & $35^{\circ} 26^{\prime} 19^{\circ} N 51^{\circ} 12^{\prime} 14^{\circ} E$ & 3.00 & 0.80 \\
\hline 10 & & & \\
\hline
\end{tabular}

Fig. 2. Concentration contours output from the ISCST3 model for the Kahrizak complex in the summer and winter. (a) Summer, (b) Winter

concluded that the AERMOD has a reasonable match to the measured data. While the values of VG and NMSE in our study were acceptable compared to Jeong [14].

The results depicted that the predicted concentrations of $\mathrm{H}_{2} \mathrm{~S}$ in the downwind would reach zero at a distance of $35 \mathrm{~km}$ from the sources in AERMOD, and at $38 \mathrm{~km}$ in ISCST3 (Fig. 3). The AERMOD predicted upwind concentrations of $\mathrm{H}_{2} \mathrm{~S}$ would reach zero at a distance of $30 \mathrm{~km}$. While the ISCST3 predicted upwind concentrations would reach zero at the distance of $35 \mathrm{~km}$ from the sources.

The AERMOD and ISCST3 predictions in the distance of 5 $\mathrm{km}$ away from the sources had a good convergence with each other. Behind $5 \mathrm{~km}$ from the sources, the difference between AERMOD and ISCST3 predictions became more distinctive. In the winter, more fluctuations in the prediction of the AERMOD were noticed, which might be attributed to the changes in weather conditions (Fig. 3).

The maximum concentrations of the AERMOD were averagely 3\% lower than ISCST3. The US Environmental Protection Agency [39] compared the predicted maximum concentrations of the models; and reported that the AERMOD's predictions were about $4 \%$ lower than that of ISCST3's estimation.
Table 4. MG, VG, FAC2, FB and NMSE Factors for AERMOD and ISCST3 Models for $\mathrm{H}_{2} \mathrm{~S}$ Prediction at the Kahrizak Complex

\begin{tabular}{lcccccc}
\hline \multirow{2}{*}{ Factor } & \multicolumn{2}{c}{ AERMOD } & & \multicolumn{2}{c}{ ISCST3 } & \multirow{2}{*}{ Limitation* } \\
\cline { 2 - 3 } \cline { 5 - 6 } & summer & winter & & summer & winter & \\
\hline MG & 0.58 & 1.39 & & 0.85 & 1.18 & $0.5-2$ \\
\hline VG & 1.35 & 1.35 & 1.03 & 1.03 & $<1.6$ \\
\hline FAC2 & 1.91 & 1.46 & 1.45 & 1.16 & $0.5-2$ \\
\hline FB & -0.12 & -0.05 & 0.02 & 0.15 & $-0.67-0.67$ \\
\hline NMSE & 0.042 & 0.022 & 0.04 & 0.04 & $<0.5$
\end{tabular}

*Patryla [38]

The management strategies can be summarized in the following: Imam Khomeini Airport as the most significant international airport of Iran, is located nearby of the Kahrizak complex. Any odor nuisance can adversely affect the airport and bring economic damage; this study helps to assess odor pollution in terms of $\mathrm{H}_{2} \mathrm{~S}$ around the airport. In addition, using the applied methodologies, the other odor compounds' influence can be evaluated; this study is helpful in future planning for locating other landfill; 

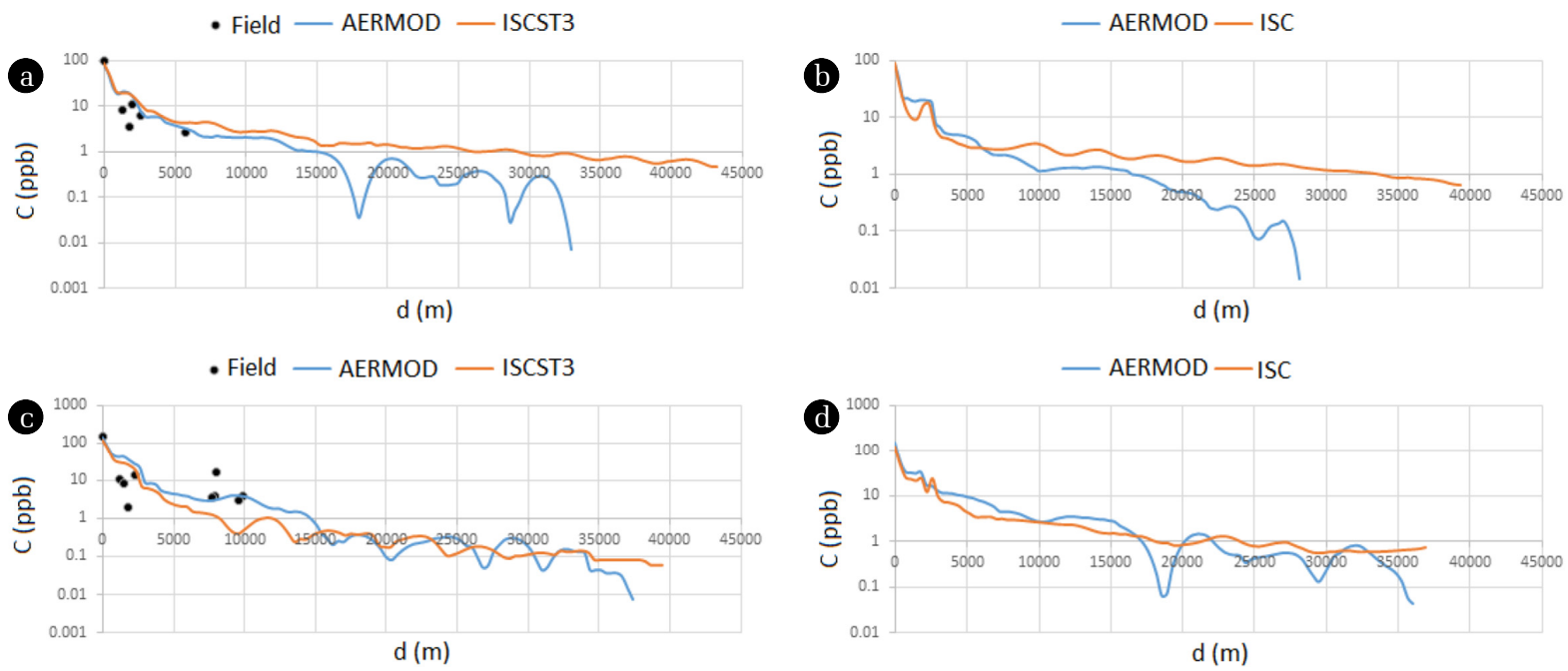

Fig. 3. Trend of AERMOD and ISCST3 predictions in the downwind and upwind of the complex at the summer and winter. (a) Summer: Downwind, (b) Summer: Upwind, (c) Winter: Downwind, (d) Winter: Upwind

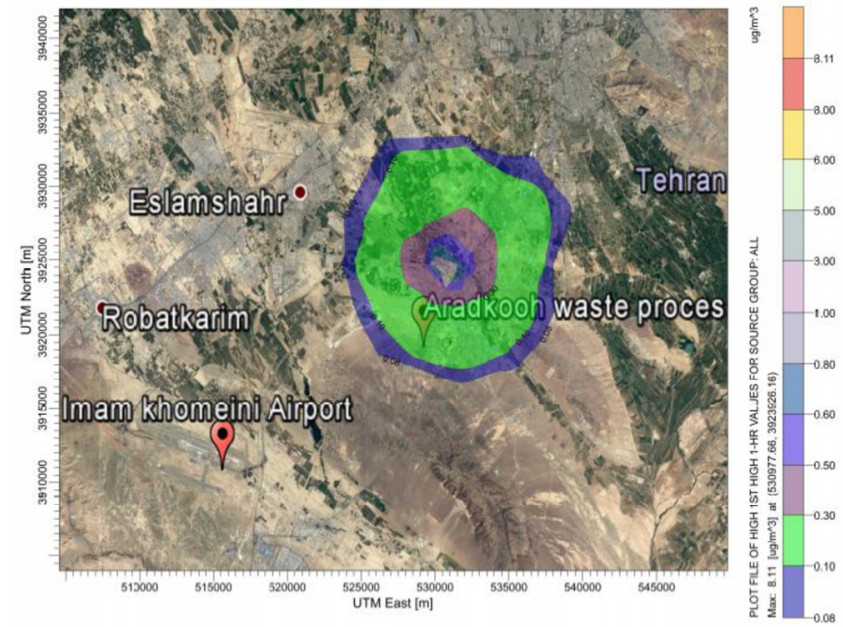

Fig. 4. The dispersion of $\mathrm{H}_{2} \mathrm{~S}$ in the wind speed of $2.22 \mathrm{~m} / \mathrm{s}$.

the urbanization development brings the population to nearby of landfills. To assess the odor pollution impacts on human health, the study of its emission is inevitable. Consequently, the results are of interest to a great variety of stakeholders such as decision makers, municipal jurisdiction and health bodies.

For the sensitivity analysis, we ran AERMOD for the wind speed of $8 \mathrm{~km} / \mathrm{h}(2.22 \mathrm{~m} / \mathrm{s})$. The results demonstrated that the highest concentration of $\mathrm{H}_{2} \mathrm{~S}$ would reach to $8 \mu \mathrm{g} / \mathrm{m}^{3}$. While in the normal condition, the maximum concentration was predicted 117 $\mu \mathrm{g} / \mathrm{m}^{3}$.

\section{Conclusions}

Considering the experimental and mathematical study of Kahrizak complex, we summarized the following conclusions:

- The field measurement during the summer and winter in- dicated that the temperature changes did not affect the concentration of $\mathrm{H}_{2} \mathrm{~S}$ in the surrounding area of the complex. $\mathrm{H}_{2} \mathrm{~S}$ levels around the leachate treatment plant were significantly higher than other areas, which might be attributed to the anaerobic treatment of leachate. The average concentration in the summer and winter were $94.7 \mathrm{ppb}$ and $145 \mathrm{ppb}$, respectively. The average concentration in the other stations was less than $10 \mathrm{ppb}$.

- The coefficient of determination $\left(\mathrm{R}^{2}\right)$, Index of agreement $(\mathrm{d})$ and Nash-Sutcliffe coefficient (E) between the predictions and field measurements were more than 0.94, which shows a good consensus between models performance and observed data. Nevertheless, the coefficients demonstrated that the AERMOD predictions were more robust in comparison with ISCST3.

- The MG, VG, FAC2, FB and NMSE indicators showed that the ISCST3 predictions were slightly more reliable than in comparison with the AERMOD results. Such that, the AERMOD results were more overestimated.

- According to the AERMOD model, the maximum predicted concentrations of $\mathrm{H}_{2} \mathrm{~S}$ was observed in the leachate treatment plant and was equal to $117 \mu \mathrm{g} / \mathrm{m}^{3}$ in the summer and $205 \mu \mathrm{g} / \mathrm{m}^{3}$ in the winter and in the case of ISCST3 it was equal to $123 \mu \mathrm{g} / \mathrm{m}^{3}$ in the summer and 171 in the winter.

- The concentration of $\mathrm{H}_{2} \mathrm{~S}$ in the wind direction reached zero at a distance of $35 \mathrm{~km}$ from sources in AERMOD and in the ISCST3 reached zero at a distance of $38 \mathrm{~km}$. In the opposite direction, this distance was $30 \mathrm{~km}$ for AERMOD and $35 \mathrm{~km}$ for ISCST3.

- According to the standard of $1 \mathrm{~h}$ concentrations of $\mathrm{H}_{2} \mathrm{~S}$ by the Massachusetts Environmental Protection Agency, which is $30 \mathrm{ppb}$; in an approximate distance of $2 \mathrm{~km}$ around the leachate treatment plant, the amount of $\mathrm{H}_{2} \mathrm{~S}$ was higher than the standard. 


\section{References}

1. ATSDR. Agency for toxic substances and disease registry. c2007 [cited 15 June 2017]. Available from: https://www. atsdr.cdc.gov/.

2. Miner JR. Nuisance concern and odor control. J. Dairy Sci. 1997;80:2667-2672.

3. Asadi M, Asadollahdardi G, Mirmohammadi M. Ammonia dispersion using experimental and modeling methods. Environ. Eng. Sci. 2014;31:643-652.

4. Asadollahfardi G, Asadi M, Youssefi M, Elyasi S, Mirmohammadi M. Experimental and mathematical study on ammonia emission from Kahrizak landfill and composting plants, Tehran, Iran. J. Mater. Cycles Waste Manag. 2015;17:350-358.

5. Guidotti TL. Hydrogen sulphide. Occup. Med. 1996;46:367-371.

6. Hessel PA, Herbert FA, Melenka LS, Yoshida K, Nakaza M. Lung health in relation to hydrogen sulfide exposure in oil and gas workers in Alberta, Canada. Am. J. Ind. Med. 1997;31: 554-557.

7. Saral A, Demir S, Yıldız S.. Assessment of odorous VOCs released from a main MSW landfill site in Istanbul-Turkey via a modelling approach. J. Hazard. Mater. 2009;168:338-345.

8. Bolyard SJ. Monitoring and modeling to estimate hydrogen sulfide emissions and dispersion from Florida construction and demolition landfills to construct odor buffering distances [dissertation]. Orlando: Univ. of Central Florida; 2012.

9. Schauberger G, Piringer M, Petz E. Diurnal and annual variation of the sensation distance of odour emitted by livestock buildings calculated by the Austrian odour dispersion model (AODM). Atmos. Environ. 2000;34:4839-4851.

10. Hanna SR, Egan BA, Purdum J, Wagler J. Evaluation of the ADMS, AERMOD, and ISC3 dispersion models with the OPTEX, Duke Forest, Kincaid, Indianapolis and Lovett field datasets. Int. J. Environ. Pollut. 2001;16:301-314.

11. Plaza C, Xu Q, Townsend T, Bitton G, Booth M. Evaluation of alternative landfill cover soils for attenuating hydrogen sulfide from construction and demolition (C and D) debris landfills. J. Environ. Manag. 2007;84:314-322.

12. Xu Q, Townsend T, Reinhart D. Attenuation of hydrogen sulfide at construction and demolition debris landfills using alternative cover materials. Waste Manag. 2010;30:660-666.

13. Latos M, Karageorgos P, Kalogerakis N, Lazaridis M. Dispersion of odorous gaseous compounds emitted from wastewater treatment plants. Water Air Soil Pollut. 2011;215:667-677.

14. Jeong SJ. CALPUFF and AERMOD dispersion models for estimating odor emissions from industrial complex area sources. Asian J. Atmos. Environ. 2011;5:1-7.

15. Rood AS. Performance evaluation of AERMOD, CALPUFF, and legacy air dispersion models using the winter validation tracer study dataset. Atmos. Environ. 2014;89:707-720.

16. Lim E, Mbowe O, Lee AS, Davis J. Effect of environmental exposure to hydrogen sulfide on central nervous system and respiratory function: A systematic review of human studies. Int. J. Occup. Environ. Health 2016;22:80-90.

17. Legator MS, Singleton CR, Morris DL, Philips DL. Health effects from chronic low-level exposure to hydrogen sulfide. Arch. Environ. Health 2001;56:123-131.
18. Doujaiji B, Al-Tawfiq JA. Hydrogen sulfide exposure in an adult male. Ann. Saudi Med. 2010;30:76-80.

19. Tehran Waste Management Organization (TWMO). Arad-Kouh waste disposal and processing complex. c2017 [cited 10 August 2017]. Available at: http://pasmand.tehran.ir/ Default.aspx?tabid $=90$.

20. Harati A. Abdollahzade R, Jamshidi R. Investigating the potential for RDF production from reclaimed landfill in Iran (case study Arad Kouh landfill in Tehran). J. Environ. Sci. Technol. 2011;13:75-82.

21. Nguyen V. The effect of weather on speed reduction on a freeway and air pollutant dispersion pattern near the freeway [dissertation]. Windsor: Univ. of Windsor; 2011.

22. Yazdi MN, Delavarrafiee M, Arhami M. Evaluating near highway air pollutant levels and estimating emission factors: Case study of Tehran, Iran. Sci. Total Environ. 2015;538:375-384.

23. Jacobs MB. Recommended standard method for continuing air monitoring for hydrogen sulfide ultramicrodetermination of sulfides in the air. J. Air Pollut. Control Assoc. 1965;15: 314-315.

24. Arya S. Air pollution meteorology and dispersion. New York: Oxford Univ. Press; 1999.

25. Wang L, Parker DB, Parnell CB, Lacey RE, Shaw BW. Comparison of CALPUFF and ISCST3 models for predicting downwind odor and source emission rates. Atmos. Environ. 2006;40:4663-4669.

26. US EPA. AERMOD: Description of model formulation. c2000 [cited September 2004]. Available from: https://www3.epa.gov/ scram001/7thconf/aermod/aermod mfd.pdf

27. Cimorelli AJ, Perry SG, Venkatram A, et al. AERMOD: A dispersion model for industrial source applications. Part I: General model formulation and boundary layer characterization. $J$. Appl. Meteorol. 2005;44:682-693.

28. Perry SG, Cimorelli AJ, Paine RJ, et al. AERMOD: A dispersion model for industrial source applications. Part II: Model performance against 17 field study databases. J. Appl. Meteorol. 2005;44:694-708.

29. US EPA. User's Guide for the AERMOD Meteorological preprocessor (AERMET). c2004 [cited 10 August 2017]. Available from: https://www3.epa.gov/ttn/scram/7thconf/aermod/aermet userguide.pdf

30. Robinson WS. The statistical measurement of agreement. Am. Soc. Rev. 1957;22:17-25.

31. Ozer DJ. Correlation and the coefficient of determination. Psychol. Bull. 1985;97:307-315.

32. McCuen RH, Knight Z, Cutter AG. Evaluation of the Nash-Sutcliffe efficiency index. J. Hydrol. Eng. 2006;11: 597-602.

33. Hanna S, Chang J, Strimaitis D. Hazardous gas model evaluation with field observations. Atmos. Environ. Part A 1993;27: 2265-2285.

34. Williams PT. Waste treatment and disposal. 2nd ed. England: John Wiley \& Sons Ltd.; 2005.

35. Occupational Safety and Health Administration. Toxic and hazardous substances, standard number. 1910.1000.table z-2, Facilities; c1996 [cited 15 August 2017]. Available from: https://www.osha.gov/pls/oshaweb/owadisp.show_docu- 
ment $?$ p table $=$ STANDARDS.

36. Massachusetts Department of Environmental Protection. Policy: Control of odorous gases at Massachusetts landfills. Waste and Recycling Policies and Guidance: Solid Waste Management Facilities; c2007 [cited 15 August 2017]: Available from: http://www.mass.gov/dep/recycle/laws/lfgaspol.doc.

37. Youssefi M. Mathematical model development for odor emission from Kahrizak landfill and composting plants toward residential cities [dissertation]. Kharazmi Univ., Iran; 2012.

38. Patryla L, Galeriua D. Statistical performances measures-models comparison. 12 September 2011; Paris. p.1-75.

39. US EPA. Comparison of regulatory design concentrations: AERMOD vs ISCST3, CTDMPLUS, ISC-PRIME. c1999 [cited June 2003]. Available from: https://www3.epa.gov/scram001/ 7thconf/aermod/compar.pdf 